\title{
Indwelling Urinary Catheter: Effect of Training on Nurses Knowledge and Skills
}

\author{
Alshaimaa M. Abdelmoaty ${ }^{{ }^{*}}$, Hend A. Sabry ${ }^{1}$, Ahmed M.Kenawy ${ }^{1}$, Eman H. ElSebaie ${ }^{1}$
}

${ }^{1}$ Public Health and Community Medicine Department, Cairo University, Egypt

\begin{abstract}
:
Background: Catheter Associated Urinary Tract Infections (CAUTI) is the most common Healthcare Associated Infections (HAIs) worldwide; the incidence has been reported to be approximately $35 \%$. CAUTI has been associated with increased morbidity, mortality, hospital cost, and length of stay. Changing the behavior towards the urinary catheter practices and renewing the nurses' awareness about CAUTI come through education.

Objectives: Assessment of nurses' knowledge and skills regarding the indwelling urinary catheter management. Design, implement and evaluate the effect of the training on nurses' knowledge and skills.
\end{abstract}

Methods : Total sample of the working nursing staff $(\mathrm{N}=190)$ in one of Cairo University hospitals, Training needs assessment were done, planning for knowledge and skills training and evaluation for the training through comparing Pre and post- tests results were done.

Results: Nurses knowledge and practice median score regarding urinary catheter management had improved after training from (50/100 to 81.25/100) and from (33.3 to 66.67) respectively. Positive correlation between knowledge and skills were maintained before and after training.

Conclusions: training for the experienced nurses about CAUTI succeeded to improve their knowledge and skills with statistically significant difference.

Keywords: Health Care Associated Infections, Catheter Associated Urinary Tract Infection, Cairo University Hospital.

\section{Introduction:}

Healthcare Associated Infections (HAIs) are major public health problems with high endemic and epidemic potentials. HAIs are the most important indicators of quality in hospitals exerting threats on patient safety, increasing morbidity, mortality and treatment cost ${ }^{(1)}$ with an estimated attributable mortality of $10 \% .{ }^{(2)}$ HAIs are largely avoidable showing a significant economic impact on both patient and population levels. ${ }^{(3)}$ HAIs rates exceeds $25 \%$ in developing countries $^{(4)}$ the highest rates were reported in the Eastern Mediterranean region hospitals. ${ }^{(1)}$ Catheter Associated Urinary Tract Infections (CAUTI) is the most common HAIs worldwide and the incidence has been reported to be approximately $35 \% .^{(5)}$ CAUTI has been associated with increased morbidity, mortality, hospital cost, and length of stay. Serious complications that could be encountered with CAUTI include: cystitis, pyelonephritis, vertebral osteomyelitis, septic arthritis, endocarditis, endophthalmitis and meningitis generally in all patients in addition to epidedemo-orchitis and prostatitis in males. (6) According to The Egyptian Ministry of health and Population, CAUTI rates in intensive care units (ICUs) were 13.05/1000 catheter-days ${ }^{(7)}$ in another study performed in ICUs of Alexandria, Egypt it was found to be $15.7 / 1000$ catheter-days. ${ }^{(8)}$

*Corresponding author: E-mail: drmaha_wahdan@med.asu.edu.eg 
The estimated daily risk of developing CAUTI ranges from $3 \%$ to $7 \%$. The longer catheterization time the higher is the risk of developing CAUTI. ${ }^{(9)}$ Some identified major risk factors that may lead to CAUTI include; inappropriate indications, inappropriate techniques of insertion as well as inadequate follow up, daily care and management. ${ }^{(10)}$

Reducing the frequency of CAUTI by up to $69 \%$ can be fulfilled by following the recommended infection control measures to control. ${ }^{(11)}$ Preventive measures that have been proved to reduce CAUTI rates include: hand hygiene prior to any urinary catheter manipulation, perineal care and daily review and follow up to limit the implementation days of catheter. ${ }^{(12)}$

These preventive scientific evidence based measures are bundled together by many institutions formulating a urinary catheter protocol based guidelines aiming at standardizing care by which patient outcomes improve. The CAUTI care bundle includes; the insertion bundle and the maintenance bundle, that ensure the daily revision of the indications for appropriate removal decision of unnecessary catheters in the proper time. ${ }^{(13)}$ CAUTI rates reduction approach is a multidirectional complex process focusing on adherence to infection prevention and control principals. ${ }^{(14)}$

Several studies emphasized the important role of education and training of nursing staff for better outcome and reduction of complication. ${ }^{(15)}$ Changing the behavior towards the urinary catheter practices and renewing the nurses' awareness about CAUTI come through education. $^{(16)}$ Changing the health care providers' behavior is considered a challenge across all healthcare facilities, targeted educational programs led to increased awareness with a positive relation between knowledge and attitude towards management of urinary catheter. ${ }^{(17)}$

Justification of the study: Integrated care bundle to prevent CAUTI in patients admitted to Cairo University Hospital requires a multidisciplinary approach and cooperation from all the stakeholders. Up till now the work load and financial constrains are the top priority of the hospital management. The lack of the bundle implementation necessitates at least an intervention that focuses on training the health care providers . Hence, education of health care providers is proved to change their behavior positively, nurses- the health care front liners encountering urinary catheter in their daily practices- are a good target to 
assess and update their knowledge about CAUTI.

The current study aimed at assessment of nurses' knowledge and skills regarding the indwelling urinary catheter management. Also, design, implement and evaluate the effect of the training on nurses' knowledge and skills.

\section{Subjects and Methods:}

An interventional study conducted in one of Cairo university hospitals, a tertiary care teaching hospital, over a period of 7 months from February 2018 to august 2018. The study participants (190) were a total sample of the working nursing staff in the hospital distributed over 22 units including 9 intensive care units (ICUs) and 13 other in-patient wards. Gathering up of the nurses required dividing them in small groups of 10-15 nurses each on different days in order not to disturb the workflow negatively. The study phases included:

1. Baseline assessment of participant nurses' knowledge and practice was conducted for two groups of nurses each week over a period of 14 weeks. This includes: Participants' knowledge assessment, was done through a self-developed \& well-organized questionnaire consisting of 2 sections. The first is for the demographic characteristics of the participants \& the other containing 16 questions on hospital acquired infections caused by invasive medical procedures generally and CAUTI risk factors and methods for prevention specifically. The questionnaire was translated from English to Arabic by the investigators and retranslated again to English assure accuracy. Its items were adopted from AHRQ (Agency for Health Care Research and Quality) \& Gould et al. ${ }^{(6,18)}$ It took the participants 30 minutes to fulfill.

Practice assessment: Each nurse was asked individually to demonstrate Foley catheter insertion on a simulation model. Each participant underwent observation and her technique was evaluated using a standardized 18-item checklist, using a 2-point scale (satisfactory, unsatisfactory).

2. Planning for the intervention: Specially designed training course was prepared in 3 weeks based on the analysis of the initial base line assessment including theoretical and practical sessions; Theoretical lecture on all infection control knowledge and practice concerning CAUTIs that nursing staff should know and practice. Arranging for the audio visual and practical training tools and required logistics were done in this phase on the correct catheter insertion technique using the standardized skill list. 
3. Interventional implementation: Was done interactively in small groups over a period of another14 weeks. The education/training day schedule included: Two theoretical sessions 20 minutes each, 15 minutes for discussion and a break of 10 minutes in between providing the required knowledge about: Hospital acquired infection: Over view ,CAUTI: risk factors and how to prevent in practical life. An educational video of 15 minutes duration was presented at the end of theoretical sessions and included information on the standard care for urinary catheterization. Another practical session of 20 minutes duration where each participant had a further opportunity to practice the insertion using the skills checklist, managed by a high nurse, followed by the educational video, to ensure better maintenance of the acquired knowledge.

To motivate the nurses for active participation distribution of official certificate approved by Cairo University Hospitals management took place at the end of training. Added to selecting the training site in a lecture hall situated in-between the wards as the environment that was suitable and comfortable for the nurses regarding the seats, ventilation, audiovisual aids and coffee breaks.
4. Post training assessment was done using the same methods of the baseline assessment and was performed after one month of conducting the training. Both knowledge \& skills were matched \& compared pre and postintervention to determine the effectiveness of the education intervention in enhancing aseptic Foley catheter insertion techniques knowledge \& practice performance in a tertiary care setting.

Statistical Analysis: Data entry, cleaning and analysis were carried out using SPSS 21.0 (SPSS Inc. IBM, USA). Descriptive statistics were used to characterize the research sample. Quantitative data was expressed using mean, standard deviation, median and interquartile range (IQR). Categorical variables were reported as percentages. Nonparametric tests of significance namely McNemar test and Wilcoxon Signed Ranks test were used to measure the change of responses of the participants before and after the intervention; the first for categorical variables and the second for continuous scores. Spearman's rho test was performed to estimate correlation between different scores before \& after the intervention. $\mathrm{P}$ value of $<0.05$ was considered significant.

Ethical considerations: Approval for the study was obtained from the research ethics 
committee faculty of medicine, Cairo University. Administrative approvals were obtained from the hospital director. Anonymity was guaranteed to all the participants. The whole data was kept confidential.

Results: Among all the participant nurses $(\mathrm{n}=190)$; the mean years of working experience is almost 20 years. One quarter of them expressed encountering the concept of infection control during their basic education curricula. However, more than $90 \%$ of them have previously attended training related to infection control with a median of two training courses and IQR of (1-3) courses all through their working years (Table 1).

Regarding participants' knowledge about Urinary tract catheterization there was a significant difference between the proportions of participant nurses responding correctly to the 16 knowledge items presented to them in the testing questionnaire before and after the intervention. Collectively their median score from 100 point was (50) before the intervention and jumped to be (81.25) after the intervention (Table 2).

The participants' practice had improved significantly in urinary catheterization management (18 items) after intervention, except for two items, for which the responses improved but not significantly, which were; "Correct leveling of urine collection bag" \& "Correct emptying of urine collection bag". Collectively, there was an overall significant improvement in practice score after the intervention (66.67 versus 33.33) (Table 3).

There was a positive moderate significant correlation between knowledge and practice scores before the intervention with a correlation coefficient of $(0.444) \& \mathrm{p}$ value $<$ 0.01 . This positive significant correlation remained after the intervention but with a correlation coefficient of (0.269), using spearman's rho test.

\section{Discussion:}

In the present study the studied nurses showed a long working experience with a median of 21 and IQR of (20-25) years. According to Madeo and Roodhouse ${ }^{(19)}$ it was expected for a qualified nurse of at least 4 years of work experience to comprehend minimally the basics of indwelling urinary catheter management best practice. These long years of experience manifested in their sincere cooperation and interaction with trainers during the workshop implementation. One quarter of the nurses declared confronting topics about infection control during their education period and more than $90 \%$ had 
previously attended training related to basics of infection control with a median of 2 training courses and IQR (1-3). None of the nurses had attended any training tackling specifically urinary catheters management and hence conducting an initial assessment for their baseline knowledge was a must. The results of the baseline assessment were found unsatisfactory. These results were done aiming at training assessment needs regarding urinary catheter management and accordingly the training sessions were conducted. The participants' median score of knowledge had jumped from 50 prior to training into 81.25 out of 100 points after implementation of the special designed training based on their training assessment needs. This is consistent with Nazarko ${ }^{(20)}$ who emphasized that in order to help updating and keeping the health personnel knowledge and skills it is important to tailor made the training design according to the need of trainees.

The total satisfactory level and the statistically significant difference in the nurses' knowledge pre and post training sessions reflects the positive effect of the training interactive approach with full active participation of the nurses based on their training needs. That is congruent with Drekonja et al. ${ }^{[21]}$ findings who stated that the significant improvement in test scores following training workshops requires explanations of concepts to apply the best practice techniques for the management of an indwelling urinary catheter is considered a highly effective form of teaching. Similarly Yoon, et al. and Fink et al. ${ }^{(15,22)}$ highlighted the role of care givers education and training especially the nurses on the urinary catheter management to ensure the best practice in favoring the patient outcomes and to reduce the possible complications that might happened.

As regards the nurses' urinary catheter management practice total competency level, results of this study revealed the highly statistically significant differences between level of acquired nurses' practices pre/post the interactive training (Practice median score of 66.67 post training versus 33.33 pre training, $\mathrm{P}<0.0001$ ). These findings indicate that the training was successful and the role of trainers was a right way in lab skills to get the best practices technique for urinary catheter management. In this context, Harrods et al ${ }^{-(23)}$ emphasized the importance of practically applying what was learned will help retaining and utilizing the acquired best practice urinary catheter management knowledge in the future daily practice from insertion to maintenance 
till safe removal. A point of view that is second to be respected in the future practice which is of extreme importance for the sustainability of the acquired best practice was mentioned by Willson et al. ${ }^{(24)}$ and Altun and Karakoc. ${ }^{(25)}$ They ensured the importance of implementing a sustained program for education, observation and continuous planned updating following the training intervention to ensure retaining and utilizing what was learned in practice.

In the current study positive correlation was found between total level of knowledge and practice before training and remained positive after training. This goes in line with the previously mentioned findings when the level of both knowledge and practice were low prior to the training intervention the correlation between them was found to be positive. When both level of knowledge and practice improved after the intervention, the correlation remained positive with better level of knowledge and practice. Similar results were stated by Oman et al. ${ }^{(18)}$ who confirmed the positive relation between knowledge and behavior among the studied nurses towards urinary catheter management. They stated that changing the nurses' behavior is considered a challenge in all healthcare facilities and the early their engagement with an interdisciplinary targeted educational initiative the increased awareness level will be achieved.

Limitations of the study: Assessment of the practice on a dummy does not necessarily reflect the usual daily behavior of the nurses during the work pressure. However it assures that nurses attain the correct knowledge. Follow up of the nurses daily practice in the future is considered a challenge, either by direct observation with the possible Hawthrone effect potential or through self assessment that tends to overestimate compliance.

Conclusion: In conclusion, refreshment training for the experienced nurses about CAUTI succeeded to improve their knowledge and practice with high significant difference. It also affirmed the correlation between nurses' knowledge and practices after the intervention.

Acknowledgment: The authors acknowledge all the participating nurses for their sincere well to develop their skills for the sake of serving the patients.

\section{Fund: None.}

\section{References:}

1. Report on the endemic burden of healthcare-associated infection worldwide. Geneva: World Health Organization; 2011. 
http://apps.who.int/iris/bitstream/

10665/80135/1/9789241501507_eng.pdf.

Accessed 13 Oct 2018.

2. Allegranzi B, Bagheri Nejad $\mathrm{S}$, Combescure C, Graafmans W, Attar H, Donaldson L, et al. Burden of endemic health-care-associated infection in developing countries: systematic review and meta-analysis. Lancet. 2011; 377:22841.

3. Annual epidemiological report on communicable diseases in Europe 2008. Report on the state of communicable diseases in the EU and EEA/EFTA countries. Stockholm: European Centre for Disease Prevention and Control; 2008. http://ecdc.europa.eu/en/publications/Publi cations/0812_SUR_Annual_Epidemiologic al_Report_2008.pdf. Accessed 13 Oct 2016.

4. Pittet, D., Allegranzi, B., Storr, S., Bagheri, N., Dziekan, G., \& Leotsako, A. Infection control as a major World Health Organization priority for developing countries. The Journal of Hospital Infection 2008 68(4), 285-292.

5. Labib, M. \& Spasojevic, N. Problem of Catheter-Associated Urinary Tract Infections in Sub-Saharan Africa. Department of Surgery, School of
Medicine. University of Zambia 2013 Dio:10.5772/5537.

6. Gould C, Craig A, Rajender K, Gretchen, David $A$ and the Healthcare Infection Control Practices Advisory Committee (HICPAC) Guideline for Prevention of Cathter Associated Urinary, CDC 2009 Available from: https://www.cdc.gov/infectioncontrol/guid elines/cauti/retrieved May 2018.

7. Gadallah MA, Awady MY Al, Bagoury LS Al, Ramy G. Effect of an Intervention Training Program on Hospital Acquired Infection Rates in Intensive Care Units of Governmental Hospitals in Egypt Objectives of the study: To measure. 2017;35(2).

8. Talaat M., Hafez S., Said T., Elfeky R., ElShoubary W. and Pimental G. Surveillance of catheter-associated urinary tract infection in 4 intensive care units at Alexandria university hospitals in Egypt 2010 38(3):222-8.

9. Horan TC, Andrus M, Dudeck MA. CDC/NHSN surveillance definition of health care-associated infection and criteria for specific types of infections in the acute care setting. Am J Infect Control. 2008 36(5):309-32. 
10. Tatham, M.M.G., MacRae, M., Tully, V., Craig, K. Development and implementation of a catheter associated urinary tract infection (CAUTI) 'toolkit'. Br. Med.J. Qual. Improv 2015 Rep. 4, 1-7.

11. Jaggi N, Sissodia P. Multimodal supervision programme to reduce catheter associated urinary tract infections and its analysis to enable focus on labour and cost effective infection control measures in a tertiary care hospital in India. J Clin Diagn Res.2012 6(8):1372-6.

12. Chenoweth, C., Saint, S. Preventing catheter-associated urinary tract infections in the intensive care unit. Crit. Care Clin. 2013: 29 (1), 19-32.

13. Lai CC, Lee CM, Chiang HT, Hung CT, Chen YC, Su LH, et al. Implementation of a national bundle care program to reduce catheter-associated urinary tract infection in high-risk units of hospitals in Taiwan. J Microbiol Immunol Infect 2017:50(4):464 70.

14. Meddings, J., Rogers, M.A.M., Krein, S.L., Fakih, M.G., Olmsted, R.N., Saint, S. Reducing unnecessary urinary catheter use and other strategies to prevent catheterassociated urinary tract infection: an integrative review. BMJ Qual. Saf. 2014:23 (4).
15. Yoon B., McIntosh S. D., Rodriguez L., Holley A., Faselis Ch. And Liappis A. P. Changing Behavior among Nurses to Track Indwelling Urinary Catheters in Hospitalized Patients.2013: Available at: http://www.dx.doi.org/10.1155/2013/4050 41

16. Kim E. L., Nowosielski I., Kallini R., Aala A. and Gottdiener A. Nurse Driven Urinary Catheter Removal- Awareness and Attitudes Survey. Journal of Hospital Medicine 2015: 10 (suppl.2) 200-210.

17. Oman K. S., Makic M. B., Fink R., Schraeder N.,Hulett T., Keech T. and Wald $H$. Nurse directed interventions to reduce catheter associated urinary tract infections. American Journal of Infection Control 2011: 10 1-6.

18. AHRQ Pub No. 15-0073-2-EF 2015.

19. Madeo M. and Roodhouse A. J. Reducing the risks associated with urinary catheter standards. Nurs Stand. 2009 25-31; 23(29):47-55.

20. Nazarko, L. (2009): Proving effective evidence based catheter management. Br J Nurs 2009:9-22; 18(7)

21. Drekonja D., Kuskowski M., and Johnson J. Internet survey of Foley catheter practices and knowledge among Minnesota 
nurses. American Journal of Infection Control, 2010: 38, no. 1, pp. 31-37.

22. Fink, R., Gilmartin, H., Richards, A., Capezuti, E., Boltz, M. \& Wald, H. Indwelling urinary catheter management and catheter-associated urinary tract infection prevention practices. In: Nurses Improving Care for Health system elders hospitals 2012: 1-6.

23. Harrod M., Kowalski Ch., Saint S., Forman J. and Krein S.Variations in risk perceptions: a qualitative study of why unnecessary urinary catheter use continues to be problematic. BMC Health Services Research 2013 Available at: http://link.springer.com/journal/12913
24. Willson M, Wilde M., Webb M. L., Thompson D, Parker D, Harwood J., Callan L. and Gray M. Nursing interventions to reduce the risk of catheterassociated urinary tract infection: part 2: staff education, monitoring, and care techniques. Journal of Wound, Ostomy \& Continence Nursing 2009:36:137-154.

25. Altun I. and Karakoc, A.The impact of an interactive workshop on the management of urinary catheterization on nurses. International Journal of Urological Nursing 2010:4(3):125-132. 
Table (1): Characteristics of the Participants Nurses at Cairo University Hospital.

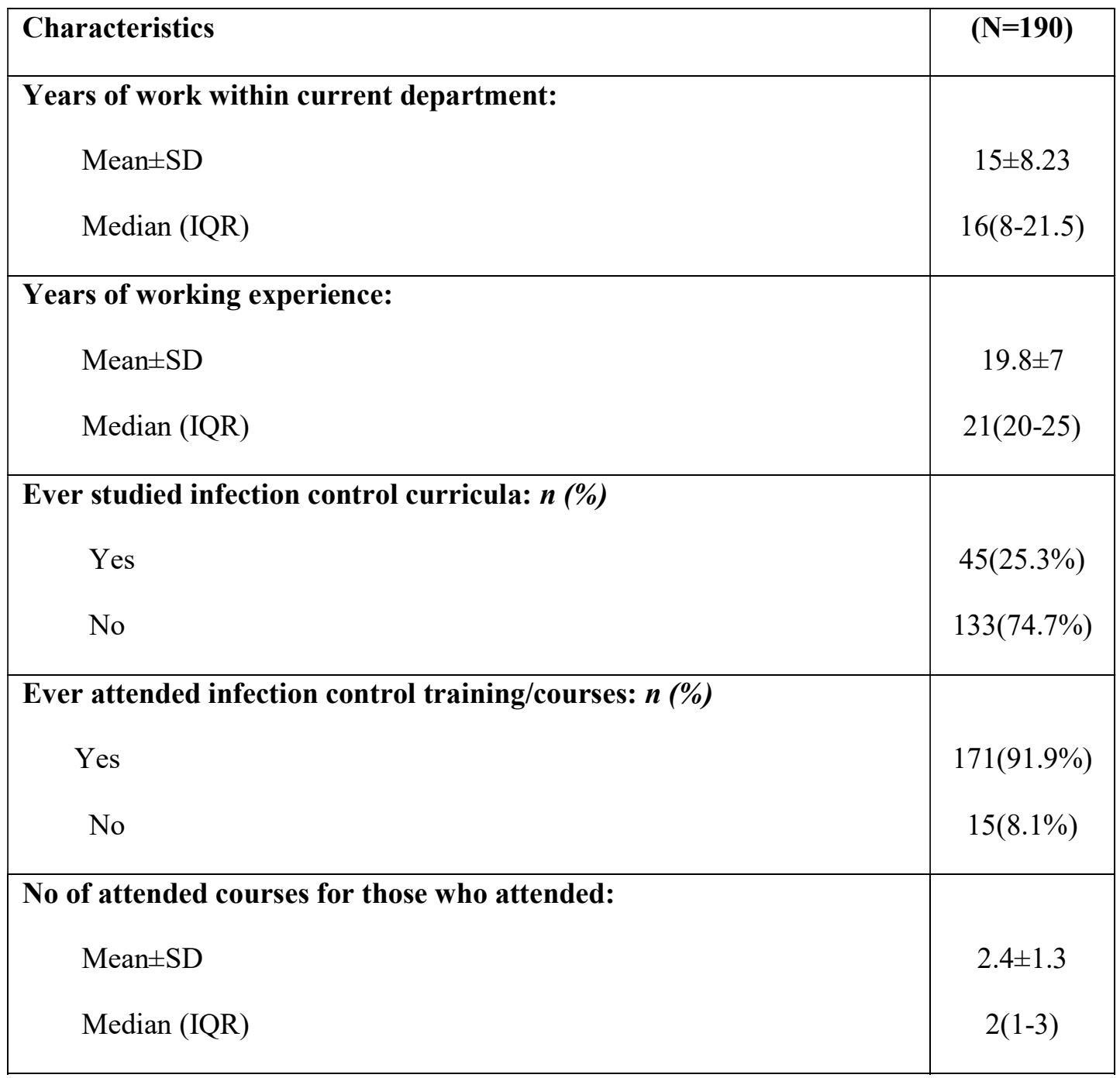

SD: standard deviation, IQR=interquartile range. Numbers may count to less than the total because of missed responses, valid percents were used. 
Table (2): Responses of participants regarding Urinary tract catheterization knowledge, before $\&$ after intervention.

\begin{tabular}{|c|c|c|c|}
\hline \multirow[t]{2}{*}{ Knowledge Items } & \multicolumn{2}{|c|}{ Correct responses of participants $n(\%)$} & \multirow[t]{2}{*}{$P$ value } \\
\hline & Before intervention & After intervention & \\
\hline Definition of invasive procedures & $47(24.7)$ & $107(56.3)$ & $0.000 *$ \\
\hline $\begin{array}{l}\text { Identification of encountered invasive } \\
\text { procedures in daily practice }\end{array}$ & $89(46.8)$ & $127(66.8)$ & $0.000 *$ \\
\hline $\begin{array}{l}\text { Invasive procedures possible } \\
\text { complications }\end{array}$ & 93(48.9) & $148(77.9)$ & $0.000 *$ \\
\hline How common are CAUTIs & $38(20)$ & $176(92.6)$ & $0.000 *$ \\
\hline Risk factors of CAUTIs & $54(28.4)$ & $118(62.1)$ & $0.000 *$ \\
\hline Diagnosis of CAUTIs & $70(36.8)$ & $120(63.2)$ & $0.000 *$ \\
\hline Sources of CAUTIs & $48(25.3)$ & $131(68.9)$ & $0.000 *$ \\
\hline CAUTI causative agents & $43(22.6)$ & $160(84.2)$ & $0.000 *$ \\
\hline Timing of urinary catheter removal & $102(53.7)$ & 148(77.9) & $0.000 *$ \\
\hline $\begin{array}{l}\text { Sometimes type of urinary catheter } \\
\text { determine timing of removal }\end{array}$ & $135(71.1)$ & $169(88.9)$ & 0.000 \\
\hline Indications of urinary catheters & $168(88.4)$ & 188(98.9) & $0.000 *$ \\
\hline CAUTI prevention methods & $103(54.2)$ & $172(90.5)$ & $0.000 *$ \\
\hline $\begin{array}{l}\text { Who is in charge of urinary } \\
\text { catheterization }\end{array}$ & $120(63.2)$ & $182(95.8)$ & $0.000 *$ \\
\hline $\begin{array}{l}\text { Water intake requirement during urinary } \\
\text { catheterization }\end{array}$ & 147(77.4) & 184(96.8) & $0.000 *$ \\
\hline Urinary drainage system requirement & $72(37.9)$ & 184(96.8) & $0.000 *$ \\
\hline $\begin{array}{l}\text { Maintenance of catheter's sterilization } \\
\text { before and after installation }\end{array}$ & $128(67.4)$ & $155(81.6)$ & $0.000 *$ \\
\hline Knowledge score: Median (IQR) & $50(31.25-62.5)$ & $81.25(68.75-93.75)$ & $0.000 * *$ \\
\hline
\end{tabular}

$\mathrm{IQR}=$ interquartile range, ${ }^{*}$ McNemar test, ** Wilcoxon Signed Ranks test. 
Table (3): Urinary Tract Catheterization Practice Among the Participant Nurses, Before \& After Intervention.

\begin{tabular}{|c|c|c|c|}
\hline \multirow[t]{2}{*}{ Practice Items } & \multicolumn{2}{|c|}{$\begin{array}{l}\text { Correct responses of participant's } n \\
\text { (\%) }\end{array}$} & \multirow[t]{2}{*}{$P$ value } \\
\hline & $\begin{array}{c}\text { Before } \\
\text { intervention }\end{array}$ & $\begin{array}{c}\text { After } \\
\text { intervention }\end{array}$ & \\
\hline $\begin{array}{l}\text { Required PPE during urinary catheter } \\
\text { installation }\end{array}$ & $32(16.8)$ & $72(37.9)$ & $0.000 *$ \\
\hline Correct application of antiseptics & $10(5.3)$ & $73(38.4)$ & $0.000 *$ \\
\hline Caring for the urethra & $10(5.3)$ & $78(41.1)$ & $0.000 *$ \\
\hline Using soap \& water in cleaning perineal area & $43(22.6)$ & 188(98.9) & $0.000 *$ \\
\hline Correct cleaning of women perineal area & $79(41.6)$ & $168(88.4)$ & $0.000 *$ \\
\hline Use of lubricant during catheter introduction & $76(40)$ & $180(94.7)$ & $0.000 *$ \\
\hline $\begin{array}{l}\text { Correct fixation of the catheter to the body of } \\
\text { the patient }\end{array}$ & $100(52.6)$ & $180(94.7)$ & $0.000 *$ \\
\hline $\begin{array}{l}\text { Fastening the urine bag to the side bars of the } \\
\text { patient's bed }\end{array}$ & $89(46.8)$ & $152(80)$ & $0.000 *$ \\
\hline Correct leveling of urine collection bag & $54(28.4)$ & $59(31.1)$ & $0.590 *$ \\
\hline Correct emptying of urine collection bag & $45(23.7)$ & $61(32.1)$ & $0.053 *$ \\
\hline $\begin{array}{l}\text { Specifying a waste container of urine } \\
\text { collection bag for each patient }\end{array}$ & $98(51.6)$ & $152(80)$ & $0.000 *$ \\
\hline $\begin{array}{l}\text { Correct evacuation of urine collection bag is } \\
\text { the duty of nurse }\end{array}$ & $98(51.6)$ & $188(98.9)$ & $0.000 *$ \\
\hline Timing of urinary catheter rinsing & $94(49.5)$ & $168(88.4)$ & $0.000 *$ \\
\hline $\begin{array}{l}\text { Can directly take urine samples from urine } \\
\text { collection bags }\end{array}$ & $26(13.7)$ & $32(16.8)$ & $0.000 *$ \\
\hline $\begin{array}{l}\text { Noticing the color and turbidity of urine can } \\
\text { be done by looking in the urine bag }\end{array}$ & $49(25.8)$ & $163(85.8)$ & $0.000 *$ \\
\hline $\begin{array}{l}\text { Inform doctors about any changes in the } \\
\text { urinary catheter system }\end{array}$ & $145(76.3)$ & $184(96.8)$ & $0.017 *$ \\
\hline $\begin{array}{l}\text { Correct arrangement for urinary } \\
\text { catheterization tray }\end{array}$ & $41(21.6)$ & 184(96.8) & $0.000 \%$ \\
\hline $\begin{array}{l}\text { Correctly documenting information upon } \\
\text { catheterization }\end{array}$ & $0(0)$ & $74(38.9)$ & $\begin{array}{l}------ \\
\end{array}$ \\
\hline Practice score: Median (IQR) & $33.33(11.11-50)$ & $\begin{array}{l}66.67(61.11- \\
77.78)\end{array}$ & $0.000 * *$ \\
\hline
\end{tabular}

$\mathrm{IQR}=$ interquartile range, ${ }^{*}$ McNemar test, ${ }^{* *}$ Wilcoxon Signed Ranks test. 


\section{الملخص العربى \\ القسطرة البولية التذخلية:تأثير التدريب على معرفة و مهارة الممرضات \\ الثيماء عبدالمعطى، هند صبرى، احمد قناوى، ايمان السباعى}

الخلفية: تعتبر عدوى المسالك البولية المرتبطة بالقسطرة هي أكثر أنواع العدوى المرتبطة بالرعاية الصحية شيوعًا في جميع أنحاء العالم ـ و تبلغ نسبة حدوثها 35\% تقريبا. تفترن عدوى المساللك البولية المرتبطة بالقسطرة بارتفاع معدلات الامرض و الوفيات و التكلفة وطول مدة الإقامة بالمستشفى. تغيير السلوك تجاه ممارسات القسطرة البولية وتجديد وعي الممرضات يتأتى بالتعليم. الأهداف: تقييم معرفة و مهار ات الممرضات فيما يتعلق بإدارة القسطرة البولية ـ تصميم وتنفيذ وتقييم تأثير التدريب على معرفة و مهارة الممرضات.

المنهجيه : عينة إجمالية (العدد=190) من طاقم التمريض العاملين باحدى مستشفيات جامعة القاهرة ـ وتم إجر اء تقييم لاحتياجات التدريب و بناءا عليه التخطيط للتدريب على المعرفة والمهارات وتقييم التدريب من خلال مقارنة نتائج اختبار ات ما قبل وبعد التدريب.

النتائج: تحسنت درجة معرفة ومهارة الممرضات فيما يتعلق بإدارة القسطرة البولية بعد التدريب من (100/50 إلى 81.25 / 100) و من (33.3 إلى 66.67) على التو الي. توجد علاقة ايجابية بين المعرفة و المهارات قبل وبعد التدريب. الاستتتاجات: نجح تدريب عدوى المسالك البولية المرتبطة بالقسطرة في تحسين معارف ومهارت الممرضات المتمرسات باختلاف ذو دلاله احصائية. الكلمات الدالة: عدوى المصاحبة للرعاية الصحية ،العدوى المصحابة للقسطرة البولية،مستشفيات جامعة القاهرة. 